\title{
The Effect of Waste Materials on the Content of Some Macroelements in Test Plants
}

\author{
Agnieszka Godlewska ${ }^{1 *}$, Marcin Becher ${ }^{2}$ \\ 1 Siedlce University of Natural Sciences and Humanities, Faculty of Medical and Health Sciences, \\ B. Prusa 14 st., 08-110 Siedlce, Poland \\ 2 Siedlce University of Natural Sciences and Humanities, Faculty of Agrobioengineering and Animal \\ Husbandry, B. Prusa 14 st., 08-110 Siedlce, Poland \\ * Corresponding autor's e-mail: godlewskaa@uph.edu.pl
}

\begin{abstract}
The study reported here was to determine the effect of an application of organic and mineral materials and their mixtures, combined with mineral fertiliser regime, on the content of selected macroelements in cocksfoot grass and maize. The trial was a completely randomised arrangement with three replicates. Two experimental factors were tested: factor A - fertilisation with organic and mineral materials ( sewage sludge fresh and composted, hard coal incineration ashes, calcium carbonate, mixture of this components) and factor $\mathrm{B}$ - mineral fertilisation. The observed effects are indicative of the legitimacy of applying sewage sludge and its mixture with hard coal ash to fertilise agricultural crops as this would reduce reliance on mineral fertiliser, which is very desirable in sustainable agriculture. Mineral fertilisation applied to both the test plants significantly reduced their contents of calcium and magnesium but it increased their content of potassium.
\end{abstract}

Keywords: sewage sludge, hard coal ash, mineral fertilisation, cocksfoot, maize

\section{INTRODUCTION}

Production capabilities of light and very light soils, which account for around $60 \%$ of ploughed land in Poland, are often limited, and improving their fertility should take into consideration economic and production aspects as well as soil environmental protection. The soils are characterised by negative organic matter balance which results in their degradation [Leszczyńska and Kwiatkowska-Malina 2011, Becher et al. 2013]. Apart from conventional organic manures, the amount of which has been on the decline in recent years, the soils can be fertilised with waste materials, in particular fresh and composted sewage sludge [Usman 2012, Godlewska 2017, Bartkowska and Dzienis 2019] which are an abundant source of both organic matter [Kalembasa and Godlewska 2009, Kalembasa and Becher 2009] and nitrogen, calcium, magnesium and some microelements [Antonkiewicz 2020]. Such a way of sewage sludge utilisation is in accordance with European Union policy which accepts its return to the environment. Agricultural utilisation of sewage sludge is perceived as a more economical method of their management than their storage or combustion [Zhang 2017]. Moreover, sustainable utilisation of sewage sludge contributes to reduced use of mineral fertilisers [Wierzbowska 2016]. However, sewage sludge parameters do not frequently meet the standards set for agricultural use. Thus, they need to be processed, e.g. by adding mineral or organic substances [Belmonte 2006, Jackson and Miller 2000] or composting [Becher et al. 2018]. Such substances include incineration ashes which, when mixed with sewage sludge, may become a material with beneficial physico-chemical parameters. Moreover, an addition of mineral waste materials such as brown or hard coal ashes or calcium oxide increases sewage sludge $\mathrm{pH}$ and thus reduces the solubility and phytoavailability of the majority of metals 
[Maksimovic et al. 2008]. Heavy metal content in sewage sludge usually does not exceed the existing standards set for its agricultural utilisation [Tiruneh 2014]. Also, they meet the basic criteria of classification as substances suitable for soil fertilisation. Farmyard manure production has declined considerably due to reduced livestock production, and sewage sludge has become an organic alternative to farmyard manure.

The objective of the study reported here was to determine the effect of an application of waste materials and their mixtures, combined with mineral fertiliser regime, on the content of selected macroelements in cocksfoot grass and maize.

\section{MATERIALS AND METHODS}

\section{Experimental Design}

A pot experiment was set up in a growing chamber of Siedlce University of Natural Sciences and Humanities, Poland. The trial was a completely randomised arrangement with three replicates. Soil material utilised in the experiment was taken from A horizon of Luvisol (table 1).

Two experimental factors were tested:

Factor A - fertilisation with organic and mineral materials:

- fresh and composed (for a period of three months) sewage sludge obtained from the municipal wastewater treatment plant in Siedlce. The sewage sludge was applied at a single rate of $5 \%$ per $1 \mathrm{~kg}$ soil material,

- a mixture of (fresh and composted) sewage sludge and hard coal incineration ashes (hard coal ash) obtained from Siedlce Power Supply

Table 1. Properties of the soil material used in the pot experiment

\begin{tabular}{|l|c|}
\hline \multicolumn{1}{|c|}{ Parameter } & Value \\
\hline Granulometric fraction: & \\
Sand $(2.0-0.05 \mathrm{~mm})(\%)$ & 74 \\
Silt $(0.05-0.002 \mathrm{~mm})(\%)$ & 21 \\
Clay $(<0,002 \mathrm{~mm})(\%)$ & 5 \\
\hline $\mathrm{pH}($ in $1 \mathrm{M} \mathrm{KCl})$ & 4.29 \\
\hline $\mathrm{TC}\left(\mathrm{g} \cdot \mathrm{kg}^{-1}\right)$ & 8.20 \\
\hline $\mathrm{TN}\left(\mathrm{g} \cdot \mathrm{kg}^{-1}\right)$ & 1.10 \\
\hline $\mathrm{TC} / \mathrm{TN}$ & 7.45 \\
\hline $\mathrm{SOM}$ & 14.1 \\
\hline $\mathrm{P}-$ available $\left(\mathrm{g}^{-1} \mathrm{~kg}^{-1}\right)$ & 0.052 \\
\hline $\mathrm{K}-$ available $\left(\mathrm{g} \cdot \mathrm{kg}^{-1}\right)$ & 0.071 \\
\hline
\end{tabular}

Company, the ratio being $2: 1(\mathrm{~m} / \mathrm{m})$ on a perdry-matter basis,

- calcium carbonate $\left(2,68 \mathrm{~g} \mathrm{CaCO}_{3} \cdot 1 \mathrm{~kg}^{-1}\right.$ of the soil material).

Factor B - mineral fertilisation:

- no NPK fertilisation

- pre-plant NPK fertilisation with urea, triple superphosphate, potassium sulfate

Pots, whose capacity was $12 \mathrm{dm}^{3}$, were filled with $10 \mathrm{~kg}$ soil material. During the growing season, soil moisture was kept at $60 \%$ field water holding capacity.

In the first study year, cocksfoot (Dactylis glomerata) was used as a test plant. Each pot was planted with $1 \mathrm{~g}$ seeds. Three cuts of grass were harvested during the growing season. In the following year, maize (Zea mays), planted at a density of 3 plants per pot, was tested.

\section{Chemical Analysis}

Prior to experiment set-up, the following soil material properties were examined:

- granulometric composition - by the aerometric method,

- $\mathrm{pH}$ in $\mathrm{KCL}$ - by the potentiometric method,

- total carbon (TC) and total nitrogen (TN) by means of a PerkinElmer ${ }^{\circledR} 2400$ Series II (TCD) Elemental Analyser, (Norwalk, CT USA), acetanilide being used as reference material $(\mathrm{C}=$ $71.09 \%$; $\mathrm{N}=10.34 \%$ ),

- $\mathrm{SOM}$ content calculated as follows: $\mathrm{SOM}=$ $\% \mathrm{TC} \cdot 1.724$,

- available $\mathrm{P}$ and $\mathrm{K}$ forms were extracted using the Egner-Riehm method and then determined by ICP-AES.

Plant material collected from pots was dried under natural conditions in a ventilated room. The air-dry plant matter was ground in a laboratory mill to obtain particles $<0.25 \mathrm{~mm}$. Then, the plant material was chemically analysed to determine total calcium, magnesium and potassium using inductively coupled plasma atomic emission spectroscopy (ICP-AES). Samples were dry-mineralised in porcelain crucibles in a muffle furnace at the maximum temperature of $450^{\circ} \mathrm{C} .10 \% \mathrm{HCl}$ was added to the ash obtained after mineralisation which was then evaporated on a sand bath until dry. Next, the samples were chemically dissolved in $10 \% \mathrm{HCl}$ and filtered through a cellulose filter to a volumetric flask after several rinsings with deionised water. 
The data obtained were used to calculate the ion rate $\mathrm{Ca}: \mathrm{Mg}$ and $\mathrm{K}:(\mathrm{Ca}+\mathrm{Mg})$ in cocksfoot and maize dry mater for each experimental combination.

Total $\mathrm{Ca}, \mathrm{Mg}$ and $\mathrm{K}$ contents in the tested organic and mineral materials were determined by ICP-AES, too, after dry mineralisation.

\section{Statistical Analysis}

Statistical calculations were conducted using the statistical software STATISTICA 13 PL (TIBCO Software, PaloAlto, USA). Mean values for the experimental factors were compared using ANOVA/MANOWA and the post-hoc Tukey test. Significance of differences was determined at $\mathrm{p}<0.05$.

\section{RESULTS AND DISCUSSION}

The chemical composition of waste materials applied in the experiment is presented in table 2. The sewage sludge content of calcium was, respectively, twice as high and four times as low as that of hard coal ash. The amount of magnesium

Table 2. The content of calcium, magnesium and potassium in D.M. in sewage sludges and ash hard coal

\begin{tabular}{|c|c|c|}
\hline Element & Sewage sludge & Ash hard coal \\
\hline \multicolumn{3}{|c|}{$\mathrm{g} / \mathrm{kg}^{-1}$} \\
\hline $\mathrm{Ca}$ & 39.6 & 21.4 \\
$\mathrm{Mg}$ & 7.64 & 8.82 \\
$\mathrm{~K}$ & 4.06 & 3.43 \\
\hline
\end{tabular}

and potassium was at a similar level in both the applied organic materials.

Calcium content in cocksfoot biomass (table 3) varied in individual cuts and fertilisation treatments. In experiments conducted by Godlewska and Kalembasa [2003], who fertilised annual ryegrass with sludge provided by Siedlce Wastewater Treatment Works, the plant content of calcium was similar to the findings of the present work. Soil liming resulted in an increase in the cocksfoot content of calcium determined in each harvested cuts compared with non-limed control plants, the increase being $36.2 \%$ in plots without NPK and 51.0\% in fertilised units. Also, liming in plots treated with sludge-ash mixes contributed to an increase in calcium content determined in all the cuts of the test plant. Sewage sludge applied in the experiment insignificantly affected the amount if calcium in cocksfoot grass. This may have been due to difficulty in taking up this element being present predominantly in organic bonds. The obtained results correspond to findings reported by Gondek and Filipek-Mazur [2006a]. An application of hard coal ash was followed by increased calcium content in the biomass of cocksfoot grass harvested at the second cut only. By contrast, an addition of ash to composted sludge significantly reduced calcium content in first-cut cocksfoot grass. Mineral fertilisation significantly reduced calcium content in the biomass of grass of all the cuts, the relationship being confirmed by research conducted by Staniak and Księżak [2008].

Magnesium content in cocksfoot grass biomass (table 4) was significantly influenced by the factors included in the experiment, as demonstrated by statistical analysis. A significantly

Table 3. The content of calcium (in $\mathrm{g} \cdot \mathrm{kg}^{-1} \mathrm{DM}$ ) in cocksfoot

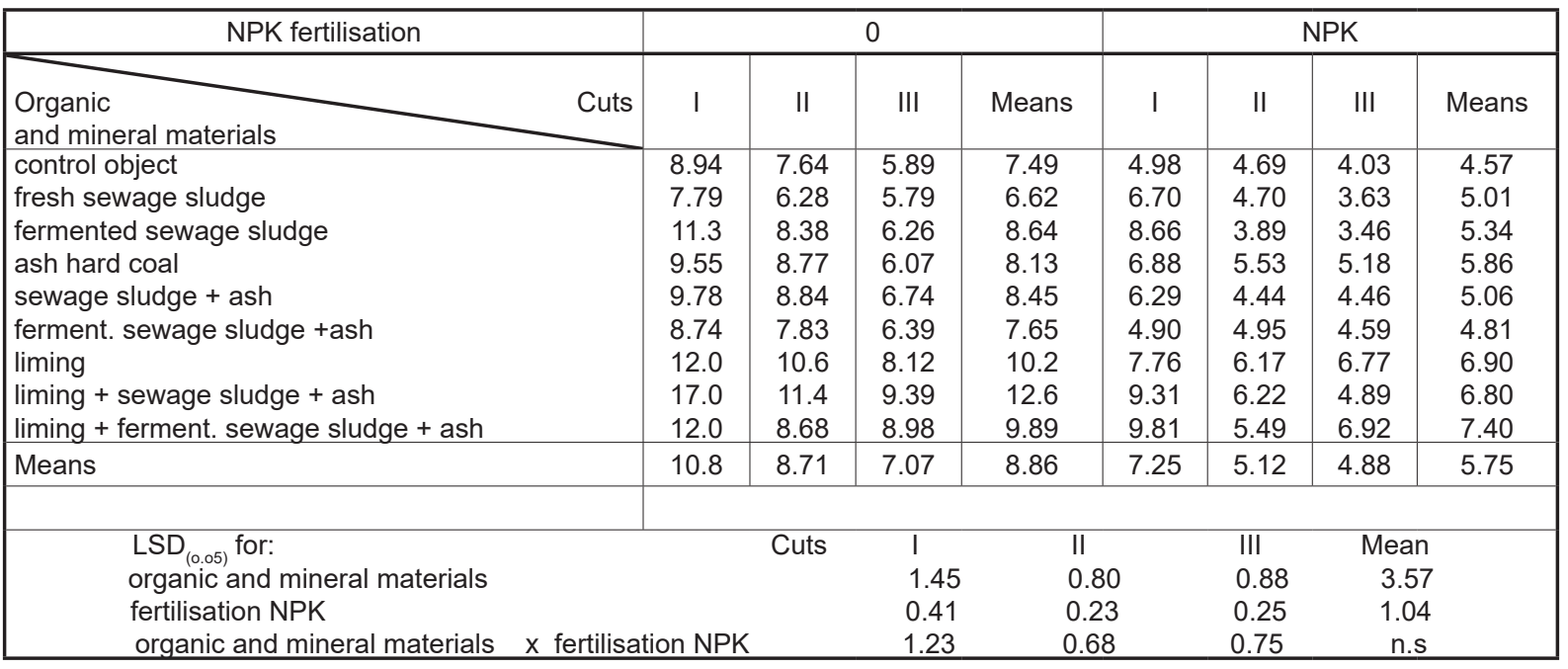


Table 4. The content of magnesium $\left(\mathrm{g} \cdot \mathrm{kg}^{-1} \mathrm{DM}\right)$ in cocksfoot

\begin{tabular}{|c|c|c|c|c|c|c|c|c|c|}
\hline \multicolumn{2}{|l|}{ NPK fertilisation } & \multicolumn{4}{|c|}{0} & \multicolumn{4}{|c|}{ NPK } \\
\hline $\begin{array}{l}\text { Organic } \\
\text { and mineral materials }\end{array}$ & Cuts & I & II & III & Means & I & II & III & Means \\
\hline control object & & 3.19 & 1.97 & 1.62 & 2.26 & 1.50 & 1.68 & 1.61 & 1.60 \\
\hline fresh sewage sludge & & 2.90 & 2.12 & 2.36 & 2.46 & 2.30 & 1.98 & 1.60 & 1.96 \\
\hline fermented sewage sludge & & 4.52 & 3.49 & 3.16 & 3.76 & 3.76 & 1.76 & 1.95 & 2.49 \\
\hline ash hard coal & & 4.99 & 3.09 & 2.66 & 3.07 & 3.07 & 2.31 & 2.38 & 2.59 \\
\hline sewage sludge + ash & & 3.42 & 3.63 & 3.54 & 3.00 & 3.00 & 2.35 & 2.37 & 2.57 \\
\hline ferment. sewage sludge +ash & & 4.50 & 3.59 & 2.92 & 2.03 & 2.03 & 2.21 & 2.64 & 2.29 \\
\hline liming & & 4.16 & 3.16 & 2.43 & 2.55 & 2.55 & 1.84 & 2.00 & 2.13 \\
\hline liming + sewage sludge + ash & & 4.88 & 2.93 & 2.96 & 3.62 & 3.62 & 2.51 & 1.31 & 2.48 \\
\hline liming + ferment. sewage sludge + ash & & 4.29 & 2.94 & 3.00 & 3.39 & 3.39 & 2.21 & 2.08 & 2.56 \\
\hline Means & & 4.09 & 2.99 & 2.74 & 3.27 & 2.80 & 2.09 & 1.99 & 2.30 \\
\hline $\begin{array}{l}\mathrm{LSD}_{(0.05)} \text { for: } \\
\text { organic and mineral materials } \\
\text { fertilisation NPK } \\
\text { organic and mineral materials }\end{array}$ & $x$ fertilisat & N NPK & Cuts & & & & $\begin{array}{l}\text { III } \\
0.36 \\
0.43 \\
0.36\end{array}$ & $\begin{array}{r}\text { Mea } \\
0 \\
\mathrm{r}\end{array}$ & \\
\hline
\end{tabular}

higher magnesium content was determined in the biomass of plants grown in plots fertilised with waste materials and their mixes, excluding fresh sewage sludge, compared with the amount of this element in control plants. Such a diverse effect of fresh and composted sewage sludge is due to a different degree of decomposition, and mineralisation rate of the organic compounds in these materials.

An addition of ash to sewage sludge, whether fresh or composted one, was followed by an increase in the plant biomass content of magnesium whereas liming of units fertilised with the sludgeash mix reduced the magnesium content in the harvested biomass. Soil liming in plots where no waste materials had been used (whether fertilised with NPK or not) increased magnesium content in the grass biomass, the differences being statistically significant. In the chemical composition of ashes, magnesium is one of dominant elements. As a result, their application beneficially affects magnesium content in plants, the finding confirmed in the work by Ciećko et al [2007]. Mineral fertilisation significantly reduced magnesium content in the biomass of cocksfoot grass, by $42.2 \%$ on average.

Potassium content in cocksfoot biomass (table 5) changed due to the effect of all the experimental factors. Soil liming significantly increased potassium content only in the biomass of second-cut plants harvested in units without NPK fertilisation, and first-cut plants growing in plots amended with mineral fertilisation. The respective increases were 18.3 and $31.2 \%$. A significantly higher amount of this element was also determined in the biomass of first-cut and second-cut cocksfoot biomass of plants fertilised with hard coal ash and NK, as well as secondcut grass fertilised with sludge-ash mixtures and NPK. Moreover, ash added to composted sewage sludge significantly increased potassium content in cocksfoot grass. Mineral fertilisation

Table 5. The content of potassium (in $\mathrm{g} \cdot \mathrm{kg}^{-1} \mathrm{DM}$ ) in cocksfoot

\begin{tabular}{|c|c|c|c|c|c|c|c|c|c|}
\hline \multicolumn{2}{|l|}{ NPK fertilization } & \multicolumn{4}{|c|}{0} & \multicolumn{4}{|c|}{ NPK } \\
\hline $\begin{array}{l}\text { Organic } \\
\text { and mineral materials }\end{array}$ & Cuts & I & II & III & Means & I & II & III & Means \\
\hline control object & & 51.2 & 31.7 & 23.6 & 35.5 & 49.1 & 49.0 & 50.0 & 49.3 \\
\hline fresh sewage sludge & & 46.8 & 21.8 & 21.1 & 29.9 & 57.5 & 46.5 & 46.4 & 50.1 \\
\hline fermented sewage sludge & & 38.1 & 29.5 & 27.2 & 31.6 & 51.8 & 56.6 & 49.5 & 52.6 \\
\hline ash hard coal & & 46.3 & 32.3 & 17.8 & 32.1 & 73.5 & 75.7 & 53.7 & 67.6 \\
\hline sewage sludge + ash & & 38.1 & 34.9 & 24.2 & 32.4 & 66.8 & 72.1 & 50.9 & 63.2 \\
\hline ferment. sewage sludge +ash & & 48.2 & 36.6 & 24.2 & 36.3 & 61.8 & 67.1 & 48.8 & 59.2 \\
\hline liming & & 50.1 & 37.5 & 20.7 & 36.1 & 64.4 & 47.9 & 33.8 & 48.7 \\
\hline liming + sewage sludge + ash & & 48.6 & 26.5 & 20.6 & 31.9 & 74.1 & 66.6 & 22.9 & 54.5 \\
\hline liming + ferment. sewage sludge + ash & & 34.5 & 33.3 & 27.7 & 31.8 & 73.9 & 58.7 & 20.1 & 50.9 \\
\hline Means & & 44.6 & 31.5 & 23.0 & 33.1 & 63.9 & 60.0 & 41.8 & 55.3 \\
\hline $\begin{array}{l}\mathrm{LSD}_{(0.05)} \text { for: } \\
\text { organic and mineral materials } \\
\text { fertilisation NPK } \\
\text { organic and mineral materials }\end{array}$ & $x$ fertilis & tion NP & Cuts & & $\begin{array}{r}\text { II } \\
5 \\
1 . \\
4 .\end{array}$ & & $\begin{array}{l}\text { III } \\
4.74 \\
1.34 \\
4.01\end{array}$ & $\begin{array}{r}\text { Means } \\
\text { n.s } \\
7.68 \\
\text { n.s }\end{array}$ & \\
\hline
\end{tabular}


significantly increased potassium content in the test grass (by as much as 66.5\%).

The contents of examined macroelements in maize grown in the second study year is presented in table 6. Calcium concentration in maize biomass varied for individual fertilisation treatments. Soil liming of units without fertilisation with waste materials, and liming of the unit amended with a mixture of fresh sludge and ash resulted in a significant increase in the maize biomass content of the discussed element, the rise being 45.1 and $79.1 \%$, respectively. When applied separately, fresh sludge, composted sludge and ash significantly increased calcium content in maize biomass, the respective increases being similar and amounting to $37.8 \%$, on average. Wen et al. [1999] reported an increase in calcium content of plants manured with sewage sludge. Mineral fertilisation had no effect on calcium content.

The maize content of magnesium was $2.46 \mathrm{~g} \cdot \mathrm{kg}^{-1} \mathrm{~d}$.m., similar values being reported by Gondek and Filipek-Mazur [2006b] for plants fertilised with a mixture of industrial and municipal sewage sludge. Magnesium content was significantly lower in the biomass of plants harvested in the control unit compared with the remaining fertilised plots, the average difference ranging from $11.8 \%$ for plants manured with fresh sludge to as much as $103.3 \%$ for plants harvested in the unit which was both limed and fertilised with a mixture of composted sludge and hard coal ash. It was found that an addition of ash to fresh sewage sludge applied in non-limed plots significantly increased magnesium content in maize biomass. Also, it was noticed that soil liming in plots without NPK significantly increased magnesium concentration in the test plant. Similar relationships were reported by Symanowicz et al. [2015]. Similarly to cocksfoot grass, mineral fertilisation significantly reduced the maize biomass content of magnesium.

Potassium content in maize biomass was predominantly affected by mineral fertilisation which significantly increased the amount of this element in the cereal, the increase being as much as $224 \%$. Fertilisation with waste materials had an insignificant influence on the concentration of potassium in the test plant, which is due to a low potassium content. Other authors [Gondek and Filipek-Mazur 2006b], who applied sewage sludge for plant fertilisation purposes, reported similar findings. However, Antonkiewicz [2007] found a significant increase in the maize biomass content of potassium following an application brown coal ashes. Soil liming in units without NPK application but treated with a mixture of sludge and ash contributed to a significant increase in the maize biomass content of potassium.

In summary, analysis of the content of the examined elements in test plants demonstrated that, in the first study year, an addition of ash to sewage sludge increased $\mathrm{Ca}, \mathrm{Mg}$ and $\mathrm{K}$ contents in cocksfoot grass, them being lower for composted sludge mixed with ash. In the second study year, reverse trends were observed as the elements determined in maize biomass increased following an addition of ash to composted sewage sludge. It can be explained by the fact that the applied organic materials had different levels of organic matter decomposition. In his study, Antonkiewicz [2020] recorded increased $\mathrm{Mg}, \mathrm{Ca}$ and $\mathrm{K}$ contents when grasses were mixed with pulses and

Table 6. The content of calcium, magnesium and potassium $\left(\mathrm{g} \cdot \mathrm{kg}^{-1} \mathrm{DM}\right)$ in maize

\begin{tabular}{|c|c|c|c|c|c|c|c|c|c|}
\hline \multirow{2}{*}{$\begin{array}{l}\text { Organic } \\
\text { and mineral materials }\end{array}$} & \multicolumn{3}{|c|}{ Content of calcium } & \multicolumn{3}{|c|}{ Content of magnesium } & \multicolumn{3}{|c|}{ Content of potassium } \\
\hline & 0 & NPK & Means & 0 & NPK & Means & 0 & NPK & Means \\
\hline $\begin{array}{l}\text { control object } \\
\text { fresh sewage sludge } \\
\text { fermented sewage sludge } \\
\text { ash hard coal } \\
\text { sewage sludge + ash } \\
\text { ferment. sewage sludge +ash } \\
\text { liming } \\
\text { liming + sewage sludge + ash } \\
\text { liming + fermented sewage sludge } \\
+ \text { ash }\end{array}$ & $\begin{array}{l}3.10 \\
3.48 \\
3.30 \\
3.04 \\
3.14 \\
4.18 \\
4.10 \\
5.25 \\
5.01\end{array}$ & $\begin{array}{l}2.27 \\
3.85 \\
4.11 \\
4.40 \\
4.04 \\
4.17 \\
3.68 \\
4.34 \\
3.83\end{array}$ & $\begin{array}{l}2.68 \\
3.66 \\
3.70 \\
3.72 \\
3.59 \\
4.17 \\
3.89 \\
4.80 \\
4.42\end{array}$ & $\begin{array}{l}1.95 \\
2.26 \\
3.32 \\
3.25 \\
3.44 \\
3.53 \\
2.37 \\
3.94 \\
4.24\end{array}$ & $\begin{array}{l}1.12 \\
1.45 \\
2.46 \\
1.65 \\
1.91 \\
2.36 \\
1.05 \\
2.11 \\
1.97\end{array}$ & $\begin{array}{l}1.53 \\
1.85 \\
2.89 \\
2.45 \\
2.67 \\
2.94 \\
1.71 \\
3.02 \\
3.11\end{array}$ & $\begin{array}{c}15.3 \\
12.9 \\
8.0 \\
8.32 \\
10.3 \\
11.7 \\
15.8 \\
8.94 \\
8.99\end{array}$ & $\begin{array}{l}27.4 \\
34.6 \\
36.8 \\
47.0 \\
33.3 \\
44.6 \\
38.4 \\
36.1 \\
26.1\end{array}$ & $\begin{array}{l}21.3 \\
23.7 \\
22.4 \\
27.7 \\
21.8 \\
28.1 \\
27.1 \\
22.5 \\
17.5\end{array}$ \\
\hline Means & 3.84 & 3.85 & 3.85 & 3.14 & 1.78 & 2.46 & 11.1 & 36.0 & 23.6 \\
\hline \multicolumn{4}{|c|}{ fertilisation NPK } & $\begin{array}{l}\text { for: } \\
0.77 \\
\text { n.s. } \\
0.65\end{array}$ & potas & $\begin{array}{l}0.60 \\
0.17 \\
0.51\end{array}$ & & $\begin{array}{l}6.79 \\
1.92 \\
5.75\end{array}$ & \\
\hline
\end{tabular}


manured with ashes mixed with sludge. Also Pesonen et al. [2016] observed a greater uptake of nutrients by plants following an application of fly ash mixed with sewage sludge.

The obtained biomass was evaluated based on feed nutritional value criteria, according to which the optimum $\mathrm{Ca}: \mathrm{Mg}$ and $\mathrm{K}:(\mathrm{Ca}+\mathrm{Mg})$ ratios should amount to, respectively, 2-3:1 and 1.62-2.2:1 [Wiśniowska-Kielian and Lipiński 2007]. The calculated ratios (table 7 and 8) were slightly different from the values assumed as optimum, the figures being significantly affected by the examined materials. In the biomass of cocksfoot grass grown in the control unit, the $\mathrm{Ca}: \mathrm{Mg}$ ratio may be accepted as optimum but for maize the value was too low. The applied waste materials exerted a negative effect on the $\mathrm{Ca}: \mathrm{Mg}$ ratio by narrowing it in the biomass of cultivated plants. Similar relationships were recorded for the $\mathrm{K}:(\mathrm{Ca}+\mathrm{Mg})$ ratio. However, in this case, the applied NPK fertilisation contributed to marked expansion of this ratio which often was outside the optimum range. The reported results correspond to findings reported by Antonkiewicz and Wisniowska-Kieljan [2014] who demonstrated that an application to crops of sludge-coal ash mixtures narrows values of the discussed ratios for alkaline soils.

Linear correlation coefficients were calculated for nutrient contents in cocksfoot biomass harvested at each cut, for the mean value calculated across three cuts and for maize. The respective significant relationships for individual elements in cocksfoot biomass were as follows: $\mathrm{r}=+0.80^{* *}$ for $\mathrm{Mg}$ and $\mathrm{Ca}$ in the first cut; $\mathrm{r}=+0.75^{* *}$ for $\mathrm{Mg}$ and $\mathrm{Ca}, \mathrm{r}=-0.70^{* *}$ for $\mathrm{Ca}$ and $\mathrm{K}$ in the second cut; $\mathrm{r}=+0.56^{* *}$ for $\mathrm{Mg}$ and $\mathrm{Ca}, \mathrm{r}=-0.70^{* *}$ for $\mathrm{Ca}$ and $\mathrm{K}$ in the third cut, a significant relationship for the mean in the biomass across three cuts being $\mathrm{r}=$ $+0.72^{* *}$ for $\mathrm{Mg}$ and $\mathrm{Ca}$. The calculated value of linear correlation for the elements determined in maize biomass was insignificant.

\section{CONCLUSIONS}

The research reported here demonstrated that calcium and magnesium contents in cocksfoot biomass and magnesium content in maize biomass were significantly higher following an application of composted sewage sludge. The effect

Table 7. Ionic relations $\mathrm{Ca}: \mathrm{Mg}$ and $\mathrm{K}:(\mathrm{Ca}+\mathrm{Mg})$ in cocksfoot

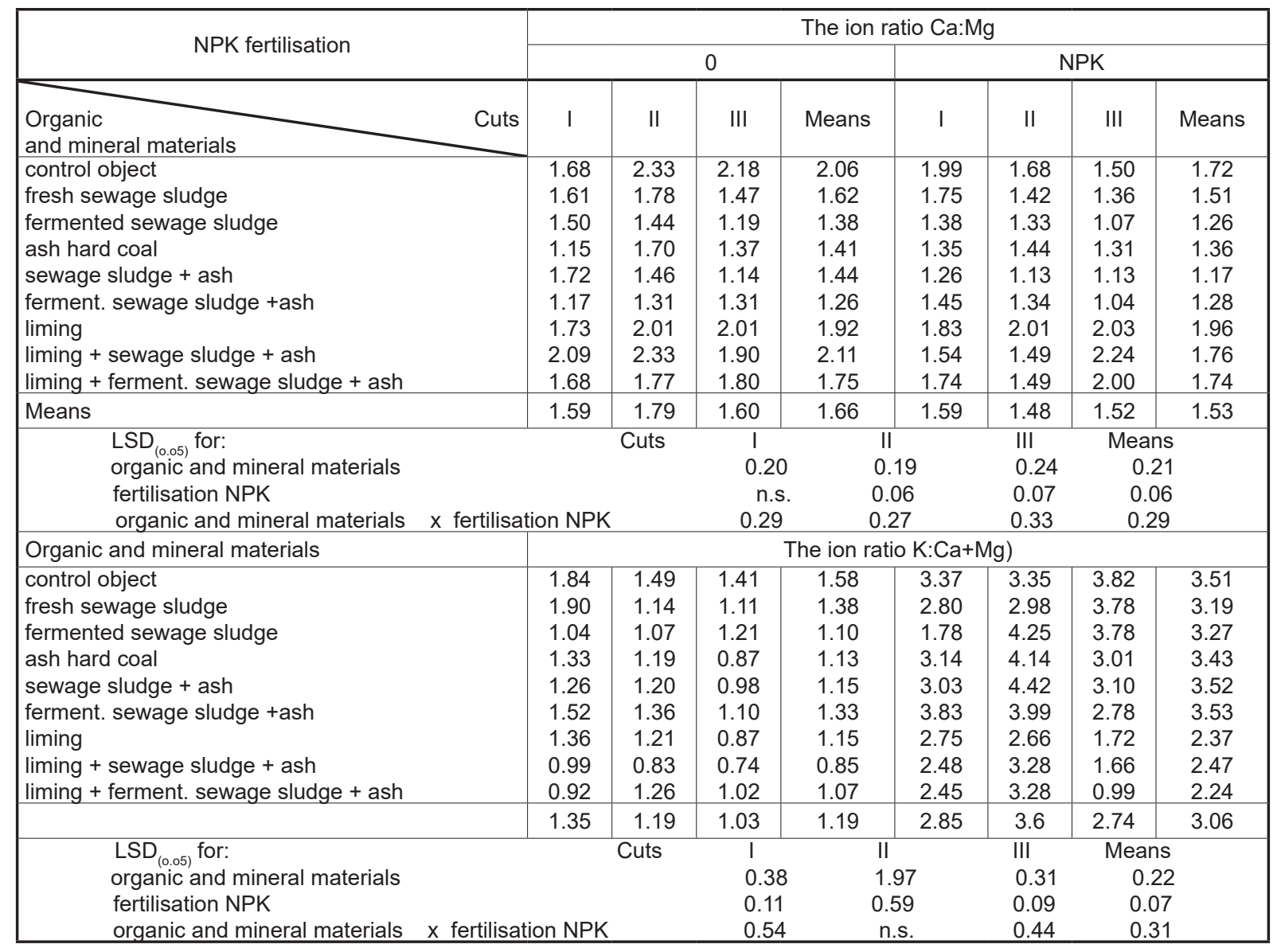


Table 8. Ionic relations $\mathrm{Ca}: \mathrm{Mg}$ and $\mathrm{K}:(\mathrm{Ca}+\mathrm{Mg})$ in maize

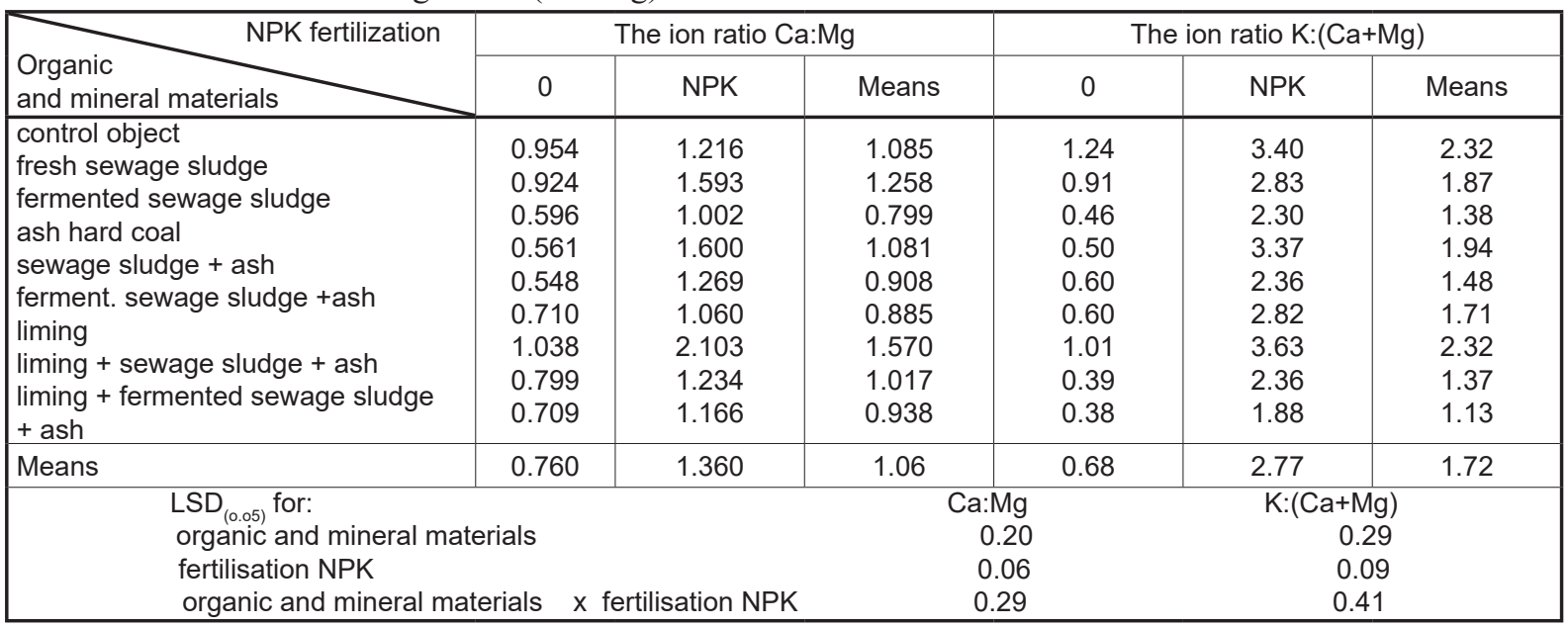

of sludge on potassium content in the cultivated plants was inconclusive. The influence of fresh or composted sludge mixed with hard coal ash had no clear effect on contents of individual elements in test plants. In the first study year, an addition of ash to fresh sewage sludge increased $\mathrm{Ca}, \mathrm{Mg}$ and $\mathrm{K}$ contents in cocksfoot biomass, them being on the decline when composted sludge was mixed with the ash. In the second study year, the reverse relationships were observed as the examined elements increased in maize biomass following an application of ash mixed with composted sludge. The observed effects are indicative of the legitimacy of applying sewage sludge and its mixture with hard coal ash to fertilise agricultural crops as this would reduce reliance on mineral fertiliser, which is very desirable in sustainable agriculture. Mineral fertilisation applied to both the test plants significantly reduced their contents of calcium and magnesium but it increased their content of potassium. The applied waste materials had a significant negative influence on the $\mathrm{Ca}: \mathrm{Mg}$ and $\mathrm{K}:(\mathrm{Ca}+\mathrm{Mg})$ ratios as they both were narrowed.

\section{Acknowledgments}

This research was supported under the research theme no. 35/20/B by the Ministry of Science and Higher Education.

\section{REFERENCES}

1. Antonkiewicz J. 2007. The effect of hard coal ashes on the amount and quality of maize yield. Polish Journal of Chemical Technology, 9(3), 20-25.

2. Antonkiewicz J., Popławska A., Kołodziej B.,
Ciarkowska K., Gambuś F., Bryk M., Babula J. 2020. Application of ash and municipal sewage sludge as macronutient sources in sustainable plant biomass production. Journal of Environmental Management, 264, 110450.

3. Antonkiewicz J., Wiśniowska-Kieljan B. 2014. Effect of furnace waste and municipal sewage sludge on the $\mathrm{Ca}, \mathrm{Mg}, \mathrm{K}, \mathrm{Na}$ and $\mathrm{P}$ uptake by a mixture of grasses. Annales Universitatis Mariae CurieSkłodowska, 69(2), 56-69.

4. Bartkowska I., Dzienis L. 2019. Utilization of sewage sludge after the prosess of autothermal digestion. Journal of Ecological Engineering, 20(8), 44-49.

5. Becher M., Pakuła K., Kalembasa D. Malinowska E. 2013. Resources and quality of organic master in arable Luvisols of Siedlce upland. Acta Scientiarum Polonorum, seria Agricultura, 12(4), 7-17.

6. Becher M., Symanowicz B., Jaremko D., Trzcińska E. 2018. Chemical composition of compost from municipal waste in the context of use as fertilizer. Acta Agrophysica, 25(3), 329-341.

7. Belmonte M., Decap J., Martinez M., Vidal G. 2006. Effect of aerobic sludge with increasing level of adaptation on abietic acid biodegradation. Bulletin of Environmental Contamination and Toxicology, 77, 861-867.

8. Boss C.B., Fredeen K.J. 2004. Concepts, instrumentation and techniques in Inductively Coupled Plasma Optical Emission Spectrometry, Perkin-Elmer, Shelton, 2004.

9. Ciećko Z., Żołnowski A.C., Chełstowski A. 2007. Residual effect of hard coal fly ashes on the chemical composition of meadow grass. Advances of Agricultural Sciences Problem Issues, 518, 23-33. (in Polish)

10. Godlewska A. 2017. Changes in the contents of selected heavy metals in test plants fertilized with sewage sludge and hadr coal ash. Journal of Ecological 
Engineering, 18(2), 97-102.

11. Godlewska A. 2018. Assessment of the content of selected trace elements in cocksfoot and maize manured with sewage sludge mixed with hard coal ash. Applied Ecology and Environmental Research, 16(3), 2141-2148.

12. Godlewska A., Kalembasa S. 2003. The content of sulphur organic and inorganic compounds in the waste activated sludges their turnover in soils and influence on plants. Part III. The content of macroelements in Lolium multiflorum. Polish Journal of Soil Science, 36(2), 175-186.

13. Gondek K. Filipek-Mazur B. 2006a. Effectiveness of sewage sludge fertilisation as assessed on basis of plant yielding and nutrient utilisation. Acta Scientiarum Polonorum Formatio Circumiectus, 8(1), 83-93. (in Polish)

14. Gondek K., Filipek-Mazur B. 2006b. Content of calcium, magnesium and sodium in plants fertilized with sewage sludge. Acta Agrophysica, 8(1), 83-93. (in Polish)

15. Jackson B.P., Miller W.P. 2000. Soil solution chemistry of a fly ash, poultry litter, and sewage sludgeamendsd soil. Journal of Environmental Quality, 29, 2430-2436.

16. Kalembasa D., Becher M. 2009. Properties of organic matter in chosen soils fertilized with sewage sludge. Environment Protection Engineering, 35(2), 165-171.

17. Kalembasa S., Godlewska A. 2009. Influence of varied nutrition and liming on $\mathrm{Cu}, \mathrm{Zn}$, and $\mathrm{Fe}$ contents at test plants. Fresenius Environmental Bulletin, 18(7a), 1210-1213.

18. Leszczyńska D., Kwiatkowska-Malina J. 2011. Effect of organic matter from various sources on yield and quality of plant on soils contaminated with heavy metals. Ecological Chemistry and Engineering S, 18(4), 501-507.

19. Maksimovic S., Blagojevic S., Pilic R. Stanojkovic, A. 2008. Quality characteristics of some Grass cultivated on fly-ash deposits of a termal Power stadion. Fresenius. Environmental. Bulletin, 17(5), 584-588.
20. Pesonen J., Kuokkanen V., Kuokkanen T., Illikainen M. 2016. Co-granulation of bioash with sewage sludge and lime for fertilizer use. Journal of Environmental Chemical Engineering, 4, 4817-4821.

21. Staniak M., Księżak J. 2008. Chemical composition of Festulolium braunii-Trifolium pratense mixtures in relation to nitrogen fertilisation and teh share components. WaterEnvironment-Rural Areas, 8,2b(24), 163-173. (in Polish)

22. Symanowicz B., Kalembasa S., Niedbała M. 2015. Impact of multi-annual mineral fertilization with NPKCa on the content and uptake of magnesium by eastern galega," Journal of Elementology, 20(4), 1011-1019.

23. Tiruneh A.T., Fadiran A.O., Mtshali J.S. 2014. Evaluation of the risk of heavy metals in sewage sludge intended for agricultural application in Swaziland. International Journal of Environmental Science, 5(1), 197-216.

24. Usman K, Khan S., Ghulam S., Khan M.U., Khan N., Khan M.A., Khan S.K. 2012. Sewage Sludge: An Important Biological Resource for Sustainable Agriculture and Its Environmental Implications. American Journal of Plant Science, 3, 1708-1721.

25. Wen G., Bates T.E., Voroney R.P., Winter J.P., Schellenberg M.P. 1999. Influence application of sewage sludge, and sludge and manure composts on plant $\mathrm{Ca}$ and $\mathrm{Mg}$ concentration and soil extractability in field experiments. Nutrient Cycling in Agroecosystems, 55, 51-61.

26. Wierzbowska J., Sienkiewicz S., Krzebietke S., Sternik P. 2016. Sewage sludge as a source of nitrogen and phosphorus for Virginia fanpetals. Bulgarian Journal of Agricultural Science, 22, 722-727.

27. Wiśniowska-Kielian B., Lipiński, W. 2007. Evaluation of the chemical composition of plants. Polskie Towarzystwo Inżynierii Ekologicznej, Krajowa stacja Chemiczno-Rolnicza, Kraków-WarszawaWrocław. (in Polish)

28. Zhang X., Wang X-Q., Wang D-F. 2017. Immobilization of Heavy Metals in Sewage Sludge during Land Application Process in China: A Review. Sustainability, 9, 2020. 